\title{
A Survey of the Bachelor of Physical Education (BPEd) Program's Awareness, Acceptability and Alignment with the University's Vision, Mission, Goals and Objectives \\ DOI: https://doi.org/10.47175/rielsj.v2i4.379
}

\author{
| Andy B. Ramos | \\ College of Education, Isabela \\ State University, Cabagan, \\ Isabela, Philippines \\ andy_milby2009@yahoo.com
}

\begin{abstract}
Every organization's vision, mission, goals, and objectives dictate its existence and direction (VMGO). Each state, university, and institution has its own VMGO, which will direct the system's strategic plans, initiatives, and activities, as well as its operations. The study determined the awareness level, acceptance, and consistency of the university's vision and mission, goals of the college, and the BPEd program objectives among students, faculty, and stakeholders. The descriptive research method was used. Students enrolled in the Bachelor of Physical Education program, faculty, and other stakeholders were the respondents of the study, with a total of 80 out of 218 respondents. A survey questionnaire was used in gathering the data. The analyzed and summarized data were then organized into a series of tables in accordance with the study's objectives. Frequency counts, percentages, and averages were utilized as descriptive statistics. The study over all revealed that stakeholders are fully aware and accept VGMO's key statements. It is also revealed from their response that the statements of the VGMO and the program activities are very much congruent. Hence, VMGO's statements' dissemination campaign and strategies are effective. This indicates further sustainability for growth and development. KEYWORDS

awareness; acceptability; VMGO; Bachelor of Physical Education program
\end{abstract}

\section{INTRODUCTION}

Every organization's vision, mission, goals, and objectives dictate its existence and direction (VMGO). Each state, university, and institution has its own VMGO, which will direct the system's strategic plans, initiatives, and activities, as well as its operations. During accreditation visits, VMGO is one of the ten (10) areas that will be accredited. Accreditation is extremely important in all fields and activities. Everything at the university or college is legitimate only if it achieves its VGMO.

Isabela State University strives to be a significant Southeast Asian research university. It aims to generate globally competitive human, technological, and service resources and services for inclusive growth and sustainable development through effective teaching, innovation, responsive community engagement, and viable asset management programs.

The College of Education at Isabela State University's Cabagan Campus is a Teacher Education Institution (TEI) tasked with developing professional educators and training future teachers committed to contributing to community development through education by: 
1.) improving educators' professional and academic educational requirements; and 2.) preparing and developing qualified and experienced basic education teachers and skilled tech teachers. The VMGO's structure and dispersion, on the other hand, have an impact on its effectiveness. To accomplish so, an educational institution's constituents must be cognizant of their VMGO and completely accept its ramifications.

\section{Statement of the Problem}

The study determined the awareness level, acceptance, and alignment with the school's strategic plan, as well as the college's aims and objectives among students, faculty, and stakeholders.

\section{Significance of the Study}

The survey results can be used to determine whether BPEd students, staff, and stakeholders understand and accept the ISU strategic vision, College of Education goals, and BPEd Program Objectives. This also acts as a basis for their continued and steadfast support of the college's efforts to completely understand and accept the strategic plan of the university, its aims, and intended outcomes by its BPEd students, professors, staff, and stakeholders. Furthermore, the results will assist the college's administration and faculty in determining the strengths and weaknesses of the college's goals and objectives, which may lead to their revision and improvement.

\section{LITERATURE REVIEW}

The strategic planning process is aided by mission statements. It explains the organization's mission and who it serves. It aims to bring different parts of the firm together around a common goal, hand over the company's strategic direction, and ensure that resources are handled correctly in compliance with this paradigm (David, 2001, cited in Erkan, 2008).

Another key aspect of strategic planning is vision statements. "A vision toward the uncertainty to determine the future, which comprises existing realities, aspirations, desires, risks, and possibilities," according to one definition. Vision forms and drives future company actions (Zel, 1997). It explains what the company seeks to become and what position it intends to attain in the future. It is the manifestation of a dream about a future ideal condition (Efil, 2004).

According to Ozdem's (2011) survey about the impact of mission and vision statements on HEIs' strategic plans, the most prevalent comments on university purpose statements are comments on offering services for the education of a trained workforce. One of the most common phrases in university goal statements is "having ubiquitous, sufficient, and competent knowledge." Universities place the greatest emphasis in their vision statements on operations connected to research activities. One of the most often underscored statements was "to become a renowned research institution both domestically and globally."

According to Bentors et al. (2017), graduate students and other study participants were fully aware, relevant, and accepting of the Naval State University (NSU) vision, mission, and graduate school aims and objectives for the various courses.

Cantürk, Kozan, et al. (2016) discovered that university entrance grades are most effective in business students' preferences at Mehmet Akif Ersoy University in their study on the effect of university mission, vision, aims, and objective statements described by universities on the significant interests of business management students. In addition, the institution's goal statement is another factor that determines their university decision. 
According to Arado, Mendoza, et al. (2019), stakeholders are aware of, understand, and accept the VMGO. They believe that their behavior is in line with these claims. The faculty have a considerably better level of awareness, grasp, and acceptance of the VMGO, as well as opinions on its consistency. Both the institute and CGS should make greater efforts to disseminate the VMGO, particularly to non-teaching sectors. Activities must be more concentrated to give them the impression that the school's activities are aimed toward achieving the VMGO.

Estrada's (2018) study found that stakeholders are generally well-informed, understand, and accept Pangasinan State University's vision, mission, and institutional goals, as well as the AB Economics Program Objectives. The data also shows that stakeholders believe the VMGO is clear and consistent among themselves, as well as with educational methods, initiatives, or activities, and that it is most likely achievable.

\section{RESEARCH METHOD}

In this study, the descriptive method was applied. During the school year 2021-2022, this was done at Isabela State University Cabagan. Students in the Bachelor of Physical Education degree, faculty, and other stakeholders were the study's respondents, with 80 out of 218 responding (See table 1). The data was gathered via a survey questionnaire. The questionnaire was developed in Google Forms and sent to the respondents via the Messenger platform. In accordance with the study's objectives, the data were examined and summarized in a series of tables. Frequency counts, percentages, and averages were utilized as descriptive statistics.

Table 1. Research respondents

\begin{tabular}{lcc}
\hline Respondents & No. of Respondents & No. of Surveyed \\
\hline Students & 199 & 72 \\
Faculty & 10 & 5 \\
Stakeholders & 10 & 3 \\
\hline TOTAL & $\mathbf{2 1 9}$ & $\mathbf{8 0}$ \\
\hline
\end{tabular}

\section{RESULTS AND DISCUSSION}

Table 2. Stakeholders' Awareness of VMGO

\begin{tabular}{lccccc}
\hline VMGO & STUDENTS & FACULTY & STAKEHOLDERS & MEAN & Description \\
\hline VISION & 3.41 & 4.00 & 3.67 & 3.69 & Fully Aware \\
MISSION & 3.40 & 3.6 & 3.67 & 3.55 & Fully Aware \\
GOALS & 3.43 & 4.00 & 3.67 & 3.70 & Fully Aware \\
OBJECTIVES & 3.35 & 4.00 & 3.67 & 3.67 & Fully Aware \\
\hline OVER ALL (WM) & $\mathbf{3 . 3 9}$ & $\mathbf{3 . 9}$ & $\mathbf{3 . 6 7}$ & $\mathbf{3 . 6 5}$ & Fully Aware \\
\hline
\end{tabular}

Table 2 shows that all stakeholders are fully aware of the university's new vision and mission, as well as the program's college targets and objectives. This indicates that the university has effective dissemination tactics for the VGMO. As a result, it's possible that stakeholders are aware with the university's vision and mission, as well as college goals and program objectives.

Salom and Florendo (2013) provide studies that back up Biddiscombe and Edmonton's (2006) assertion that members of a company must be aware of their VMGOs since these statements are a critical component of strategic management in order to reach new heights. 
Table 3. Stakeholders level of Acceptance of the VGMO

\begin{tabular}{lccccc}
\hline VMGO & STUDENTS & FACULTY & STAKEHOLDERS & MEAN & Description \\
\hline VISION & 3.64 & 4.00 & 3.67 & 3.77 & Fully Accept \\
MISSION & 3.64 & 4.00 & 3.67 & 3.77 & Fully Accept \\
GOALS & 3.65 & 4.00 & 3.67 & 3.77 & Fully Accept \\
OBJECTIVES & 3.54 & 4.00 & 3.67 & 3.74 & Fully Accept \\
\hline OVER ALL (WM) & $\mathbf{3 . 6 2}$ & $\mathbf{4 . 0 0}$ & $\mathbf{3 . 6 7}$ & $\mathbf{3 . 7 6}$ & Fully Accept \\
\hline
\end{tabular}

The table above reflects that stakeholders accept the VGMO fully. Their full acceptance of the VGMO indicates that they understand and value its statements. It clearly manifested how stakeholders agree with and support the statements of the university's VMGO, realizing that it helps lead them to a better future and knowing what to accomplish. Hence, the VMGO's success is determined by its design and transmission to be realized, all members of an academic institution must be familiar of the VMGOs (Compelio et al., 2015).

Table 4. The Level of Congruence between the Implementation of VGMO and Educational Practices and Activities

\begin{tabular}{|c|c|c|c|c|c|}
\hline VMGO & STUDENTS & FACULTY & STAKEHOLDERS & MEAN & Description \\
\hline VISION & 3.47 & 4.00 & 3.67 & 3.71 & $\begin{array}{l}\text { Very Much } \\
\text { Congruent }\end{array}$ \\
\hline MISSION & 3.47 & 4.00 & 3.33 & 3.6 & $\begin{array}{l}\text { Very Much } \\
\text { Congruent }\end{array}$ \\
\hline GOALS & 3.50 & 4.00 & 3.33 & 3.61 & $\begin{array}{l}\text { Very Much } \\
\text { Congruent }\end{array}$ \\
\hline OBJECTIVES & 3.40 & 4.00 & 3.33 & 3.58 & $\begin{array}{l}\text { Very Much } \\
\text { Congruent }\end{array}$ \\
\hline OVER ALL (WM) & 3.46 & 4.00 & 3.41 & 3.62 & $\begin{array}{l}\text { Very Much } \\
\text { Congruent }\end{array}$ \\
\hline
\end{tabular}

Table three (4) reveals through the responses among stakeholders that the VGMO and the educational activities are very much congruent. The findings imply that activities of the university, college, and program adhere to VMGOs statements. Thus, the findings also parallels with Tan and Borres (2020) that findings translate the outcomes of an institutional strategic planning conducted and implemented by each university or college.

\section{CONCLUSION}

The study looked at how well university stakeholders understood and accepted the institution's mission and vision, the college's aims, and the Bachelor of Physical Education Program's program objectives, as well as how well the university's educational practices and activities aligned with the statements. The study over all revealed that stakeholders are fully aware and accept VGMO's key statements. It is also revealed from their response that the statements of the VGMO and the program activities are very much congruent. Hence, VMGO's statements' dissemination campaign and strategies are effective. This indicates further sustainability for growth and development.

To ensure greater validity, the study recommends that a larger study be conducted. A qualitative study could also be done to fully describe the constituents' awareness and acceptability of the VMGO. 


\section{REFERENCES}

Arado, L., Mendoza, A. et al. (2019). Awareness, Understanding, Acceptance, and Congruency of the PIT Vision and Mission, College Goal and Program Objectives. International Journal of Science and Management Studies (IJSMS). 2(2) E-ISSN: 25815946.

Bentor, S., Bentor, P., et, al. (2017). Awareness, Acceptability, and Relevance of the Vision, Mission, Goals, and Objectives of the Programs of Naval State University Graduate School. International Journal of Sciences: Basic and Applied Research. 32(1), pp 181206.

Cantürk, N., Kozan, M. et al. (2016). The Effect of Mission, Vision, Aims, and Objectives statement defined by the Universities in Major Preferences of Business Management Students.

Compelio, K. J. T., Caranto, L. C., \& David, J. J. (2015). Awareness, understanding, and acceptance of student nurses of the vision, mission, goals and objectives of Benguet State University. International Journal of Nursing Sci-ence, 5(1), 20-27.

Efil, İ. (2004). İşletme yönetimi. İstanbul: Aktüel Yayınları.

Erkan, V. (2008). Kamu kuruluşlarında stratejik planlama. Türkiye uygulaması ve kuruluşlarda başarıyı etkileyen faktörler. Ankara: DPT Yayınları.

Estrada, J. (2018). Awareness and Acceptability of the Vision, Mission and Institutional Goals of Pangasinan State University and AB Economics Program Objectives. South East Asian Journal of Science and Technology.3(1)

Salom, M. and Florendo, D. (2013). Awareness, Acceptability and relevance of the Vison, Mission, Goals and Objectives of the BSEMT Program. E-International Scientific Research Journal, 5(1), ISSN 2094 - 1749

Ozdem, G. (2011). An Analysis of the Mission and Vision Statements on the Strategic Plans of Higher Education Institutions. Kuram ve Uygulamada Eğitim Bilimleri. Educational Sciences: Theory \& Practice - 11(4), 1887-1894

Pelicano, A. and Lacaba, L. (2016). Awareness and Acceptability of the Vision, Mission Goals and Objectives of Eastern Samar State University. International Journal of Innovation and Research in Educational Sciences. 3(6), ISSN (Online): 2349-5219

Tan, D. and Borres, T. (2020). Awareness, Acceptability, consistency and clarity of the Vission, Mission, Goals amd Objectives of Central Mindanao University and its Congruence to Outcomes-Based Instruction: A Preliminary Result. Sci.Int.(Lahore),32(1),93-98

Zel, U. (1997). Harekete geçirici liderlik ve işe yönelik liderlik. Ankara: MPM Yayını. 